\title{
A Review of the Research on Pre-service English Teachers' Professional Development Based on Mobile Technology*
}

\author{
Miaomiao Gao \\ School of Foreign Languages, Chongqing Normal University, Chongqing, China \\ Xifang Tu \\ School of Foreign Languages, Chongqing Normal University, Chongqing, China \\ Junshui Li \\ School of Foreign Languages, Chongqing Normal University, Chongqing, China
}

\begin{abstract}
Great changes have taken place in educational methods under the background of "internet plus", and the emergence of mobile learning indicates that there is another effective way for the development of pre-service teachers. This study takes the related papers published from 2008 to 2020 as the research objects, summarizes the research status of MALL in China from the aspects of concept definition, research methods and research topics, and analyzes the existing problems and development trends. The results show that in recent years, the research development of mobile learning at home and abroad has been accelerated, and the research objects and topics are diverse, but the research on the dimensions of pre-service English teachers is less, which needs to be strengthened urgently.
\end{abstract}

Index Terms - mobile technology, pre-service English teacher, literature review

\section{INTRODUCTION}

Most of today's pre-service teachers are post-90s and post-00s, They're the generation that grew up with the Internet, recognized as "digital aborigines ". There are four features (Chen Jianlin). (1)They are the generation of technology. From birth into the era of rapid development of information technology, Using electronic products has become the norm in their lives, So technology became part of their lives; (2) They are the generation who read pictures. Young pre-service teachers getting the information from an early age through lots of pictures, movies, anime, advertising has become their habits; (3) They are an innovative generation. With the vast resources of the information age, That provided the conditions for their innovation, Promote their desire for innovation; (4) They are an eager generation. The Internet makes people's sense of distance disappear. These pre-service teachers are used to the speed of the Internet. To get information, they formed the habit of advocating change and paying attention to efficiency. With the initiate of the Lifelong Education and the concept of 'teacher is researcher', the teacher has become both learner and researcher. And pre-service teachers, concerned its teaching idea advanced, the higher teaching enthusiasm, the firm teaching belief, have undoubtedly become a major user and beneficiary of mobile learning.

From the perspective of foreign language teaching, the use of mobile assisted language learning technology is an efficient method to promote effective teaching and individualized learning. At present, many foreign language teachers begin to pay attention to how to use mobile technology to improve their professional ability. Mobile aided language learning (MALL, Mobile Assisted Language Learning) has become another hot topic in theory and practice after computer aided language learning (CALL, Computer Assisted Language Learning) in China.

Nowadays, as teachers with the characteristics of the new era, if they still improve their own professional accomplishment in a traditional way, they obviously can no longer meet their learning aspirations and needs. It is impossible to meet the needs of full teachers in the future, such as cross-cultural awareness and mobile teaching. The rapid development of information technology under the background of "Internet" brings opportunities and challenges to pre-service foreign language teachers in the 21 st century. They should not only master the operation and application of various multimedia technologies, but also maintain a keen sense of smell at all times, so as to draw teaching resources from various modern information channels such as mobile information networks, renew teaching concepts and enhance professional literacy. It can be seen that teachers must rely on mobile language assisted learning technology to realize the development and promotion of their professional ability according to the change of information learning mode. Therefore, the purpose of this study is to study the purpose, frequency, effect and evaluation of the use of mobile

\footnotetext{
* Project Supported by Postgraduate Research Innovation Project in Chongqing (Grant No.CYS20229)
} 
assisted language learning technology by pre-service English teachers.

\section{CORE CONCEPTS}

\section{A. Mobile Learning}

At present, there is no exact definition of the concept of mobile learning, experts and scholars in the field express their opinions and understand and interpret mobile learning from different angles. This paper synthesizes the viewpoints of scholars at home and abroad (Clark Quinn, 2000; Cui Guangzuo, 2001; Chen Zhenzhen, 2019), and gives the following explanation: Mobile learning refers to a new learning form that uses wireless mobile communication network technology and wireless mobile communication devices (such as smart phones, tablet PCs PDA, smart watches, etc.) to obtain educational information, educational resources and educational services. Compared with other forms of learning, mobile learning has the characteristics of learning convenience, individualized teaching, rich interaction and context relevance. Mobile learning is the product of grafting mobile computing technology and digital learning technology, which represents the future of learning.

\section{B. Pre-service English Teachers}

As a professional term, "pre-service teacher" appeared in teacher education in Europe and America in 1960s, but the group it refers to was not clearly defined. Until 1985, Japan officially defined "pre-service teacher" as "teacher education is a professional education for training teachers, which can be carried out continuously through three stages: pre-service training, induction training and on-the-job training" in the book Encyclopedia of International Education (English version), thus defining the students who are in the stage of professional pre-service training as pre-service teachers.

Mingucci (2002) believe that teachers' professional development refers to the continuous improvement of teachers' knowledge, thought and teaching effect, which is regarded as various means adopted by teachers in the process of improving teaching practice, emphasizing teachers' experience and professional knowledge. The representative views of teachers' professional development in China are as follows: Xiao Liping (2002) pointed out that teachers' professional development is a process of enhancing teachers' professionalism and improving teachers' professional quality, emphasizing that teachers should imagine their own career development goals from the perspective of personal development, improve their education and teaching ability through learning and further education, and maximize their life value; According to Tian Han (2014), teachers' professional development refers to the process in which teachers acquire professional skills in education and teaching, form professional ideals, professional ethics and professional abilities, and achieve professional autonomy through continuous professional education, relying on professional organizations, special training systems and management systems.

English teachers' professional development is the concretization of teachers' professional development at the discipline level, Wen Qiaoping (2007) defined the concept of "foreign language teachers' professional development" as a dynamic process in which foreign language teachers take the need of self-development as the driving force and constantly develop and improve their professional intelligence and belief system through continuous learning and reflection in the teacher education mechanism.

Therefore, in this study, the professional development of pre-service English teachers means that English normal students or postgraduates who are still in the "pre-service" stage and promote their professional development by improving their educational and teaching knowledge and professional knowledge. In recent years, with the application of information technology in education and teaching, pre-service English teachers have more and more means to improve their professional development, such as distance education and mobile learning.

\section{DATA SOURCES AND ANALYSIS}

The selected papers in this study are from CNKI, and the literature published from 2008 to 2020 is searched on CNKI. Taking the periodical database of CNKI as the source database and using its advanced retrieval function, "mobile learning", "English teacher" and "pre-service" were respectively entered in "subject" for precise retrieval. The retrieval time was limited from 2011 to 2020, and a total of 219 papers were retrieved. Through content analysis, 9 papers that are not related to mobile language learning are eliminated, and the remaining 210 papers are taken as research objects. This study adopts the content analysis method to describe the current situation of the professional development of pre-service English teachers in mobile assisted language learning (MSLL) in China in the recent ten years through the two dimensions of research trends and research topics. In addition, statistical analysis is used to summarize the research status of "mobile learning" and "pre-service English teachers" at home and abroad by referring to the research contents and types of high-frequency literature, and draw conclusions.

\section{RESEARCH RESULTS}

In recent years, research on mobile learning has been hot, and few scholars focus on the professional development of pre-service teachers supported by mobile learning. Abroad, Frohberg has applied short message service to the training of pre-service teachers and obtained positive experimental results, which further proves the effectiveness of mobile 
learning. Golonka(2012) made a review of technology types and their effectiveness based on technologies. Frohberg \& C. Göth \& G. Schwabe. (2009) got a critical analysis of the state of the art by their mobile learning projects. Domestic Lu Yingbo and ZhiPing(2013) apply basic theory of constructivism teaching, teaching design and interactive teaching method as the theoretical guidance, starting from the three dimensions of mobile learning mode design, mobile language learning content design and mobile learning foreign language teaching mode architecture, and they put forward constructive ideas for mobile learning, therefore, more English pre-service teachers develop their professional ability and open up a new direction. Li Gang(2019) et al. found through the investigation and data statistics of the six major abilities of 2015 English normal college students in the educational practice of Hunan University of Arts and Science that normal college students generally adopt mobile learning in teaching design and teaching practice to improve and develop their professional abilities. The research also points out that under the background of "Internet plus", the professional development of pre-service teachers assisted by mobile technology is definitely effective.

Under the background of Internet plus, the educational mode has undergone a great change, and mobile assisted language learning has emerged in this environment. The author searched CNKI with the title of "mobile learning" and including "English Teacher", and made a quantitative visual analysis of the results:

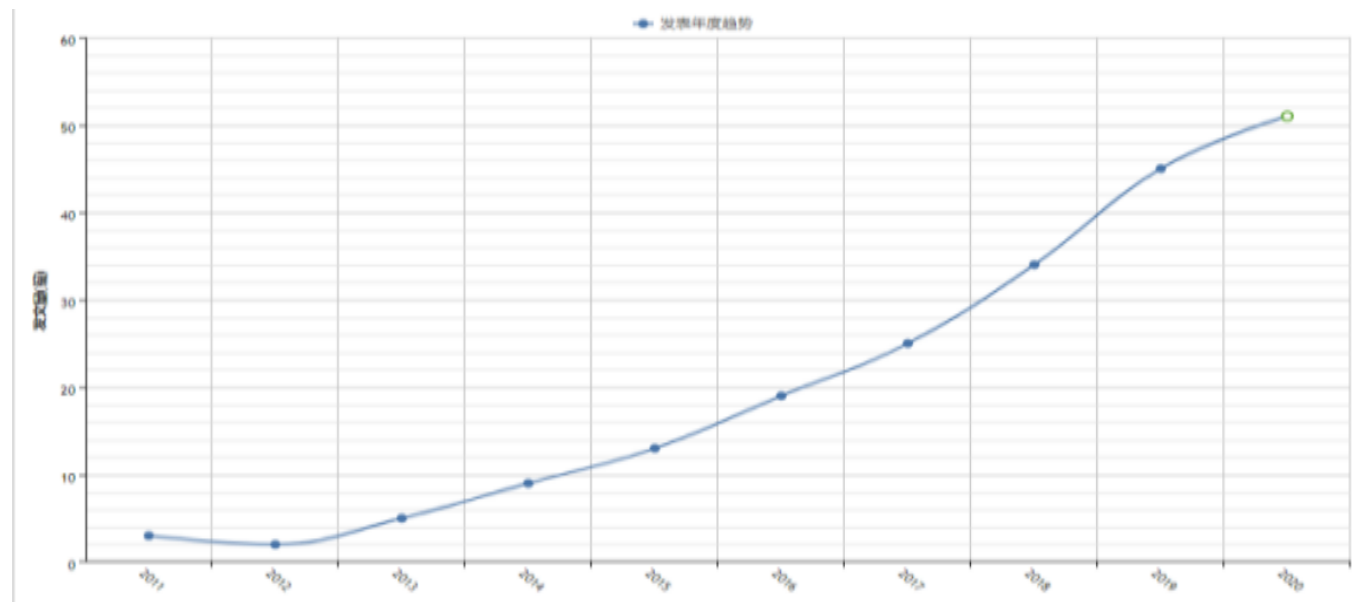

Figure 1 Distribution of publication years of relevant researches on Mobile learning pre-service English teachers

In terms of the overall trend of publication volume, although the development of mobile technology has been going on for nearly 30 years, researches on pre-service English teachers supported by mobile technology were mainly started in 2011, but few relevant literatures were published before 2015, and the development of researches on English teachers was relatively slow. In recent 5 years, it has developed rapidly and has a trend of sustainable development.

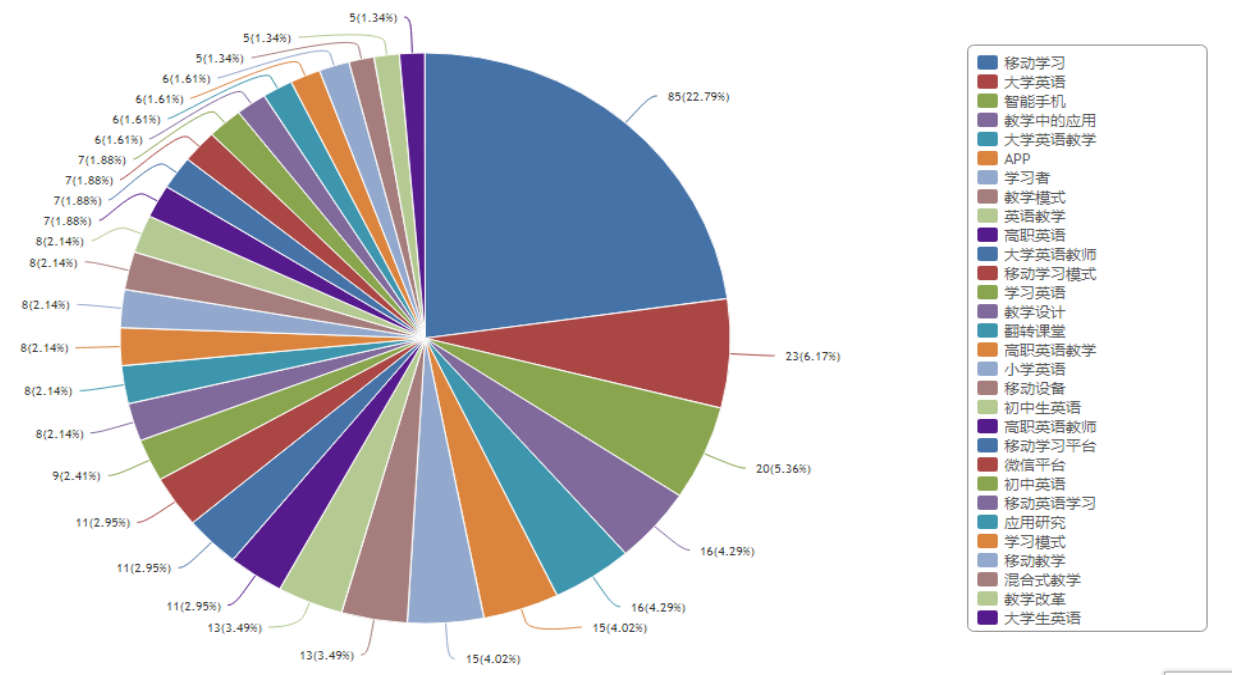

Figure 2 Distribution of relevant research topics for English teachers under mobile learning

From the perspective of the topic distribution of mobile learning and English teachers, the researches in recent years mainly focus on college English, mobile learning platform, mobile learning model and in-service English teachers, and less on the professional development of pre-service English teachers. Therefore, this paper will focus on the research on the professional development of pre-service English teachers supported by mobile technology. 
Under the background of Internet Plus, the educational mode has undergone a great change, and mobile assisted language learning has emerged in this environment. Although mobile assisted language learning because of the research history of the development of science and technology conditions is less than 30 years, but under the move tool explosive changes several times over the years, mobile learning methods are becoming more and more popular. Smart phones, smart tablet, laptop, smart watches almost penetrate in People's Daily life, such as language of mobile learning research both at home and abroad have explosive growth. The author reviews and analyzes the relevant literature on mobile assistive language learning technology at home and abroad as follows.

TABLE 1

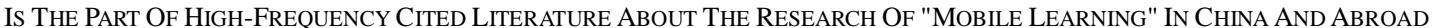

\begin{tabular}{|c|c|c|c|c|c|}
\hline 序号 & 文献名称 & 作者 & 出版年份 & 类型 & 出版源 \\
\hline 1 & $\begin{array}{l}\text { Personalized mobile English vocabulary learning } \\
\text { system based on item response theory and learning } \\
\text { memory cycle }\end{array}$ & Chen, C. M., \&.Chung, C. J & 2008 & [J] & Computers \& Education \\
\hline 2 & $\begin{array}{l}\text { Using audioblogs to assist English-language } \\
\text { learning: an investigation into student perception }\end{array}$ & Comac, L & 2008 & [J] & Computer Assisted Language Learning \\
\hline 3 & Will mobile learning change language learning? & Kukulska-Hulme, A & 2009 & {$[\mathrm{~J}]$} & ReCall \\
\hline 4 & $\begin{array}{l}\text { Use of academic podcasting in the foreign language } \\
\text { classroom }\end{array}$ & Abdous, M. H.et & 2009 & [J] & ReCall \\
\hline 5 & a review of technology types and their effectiveness & Ewa M. Golonka.et & 2014 & [D] & Computer Assisted Language Learning \\
\hline 6 & 微信公众平台支持英语阅读教学的实验研究 & 蒋银健 & 2016 & {$[\mathrm{~J}]$} & 外语电化教学 \\
\hline 7 & 基于移动学习模式的语言形式聚焦探究 & 曾䟚, 于连芬 & 2017 & {$[\mathrm{~J}]$} & 外语电化教学 \\
\hline 8 & 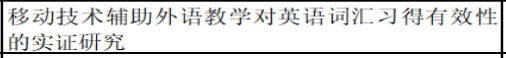 & 李思索, 高原 & 2016 & {$[\mathrm{~J}]$} & 外语界 \\
\hline 9 & 智能手机辅助外语课堂教学中的学习投入研究 & 陈真真 & 2019 & {$[\mathrm{~J}]$} & 外语电化教学 \\
\hline 10 & \begin{tabular}{|l} 
游戏化移动学习对大学英语学习者词汇学习的有效 \\
性研究
\end{tabular} & 凌茜, 王皓, 王志浩 & 2019 & {$[\mathrm{~J}]$} & 外语电化教学 \\
\hline
\end{tabular}

Based on the detailed analysis of the above literature and the reference of relevant literature, the author finds that the research results at home and abroad are as follows:

In terms of research content, in the past decade, based on the existing theories and achievements of mobile learning, foreign mobile learning mainly discusses the optimization and integration of technology and curriculum, demonstrates the practical significance and value of mobile technology equipment for English language learning, and presents and analyzes the effect of mobile learning system on language teaching. In China, mobile learning mainly focuses on the following aspects: related technology research of mobile learning system, software development research of mobile learning terminal, development research of mobile learning curriculum, standardization research of mobile learning system, theoretical research and empirical research.

In terms of research types, there are few pure theoretical researches on mobile learning abroad, most of which are the introduction of new technologies and new ideas, or the practice summary evaluation based on a certain vision. The practice field involves all levels of society, such as primary and secondary education, higher education, vocational education, distance education and so on. Since the research on mobile learning started 6 years later in China than in the rest of the world, theoretical research is in the majority. Especially, there are relatively few empirical or investigation studies and applied studies on the introduction of foreign ideas, and the research objects are mainly teachers and students in universities.

Above related literature on the "mobile assisted language learning", this project has the following enlightenment: in recent years, mobile learning research will practice at home and abroad research as the main body, in both the international and domestic research, mobile learning application research have absolute superiority, with the university scientific research platform as well as the ownership of the mobile devices of university students have a lot to do. Domestic scholars on the multi-faceted mobile learning both at home and abroad, to the development of the current domestic mobile learning put forward the corresponding proposal, for example, research mode and method should be diversified, research focus should be given a heavier "technique" back to "learning", the object of study should be expanded to the field of basic education, etc., and compared with foreign research field, is also lack of domestic research for English teachers, and related research about pre-service teachers is even less. Therefore, as pre-service English teachers, it is necessary for us to take the professional competence development of pre-service English teachers as the research object for the current booming mobile learning.

\section{B. Research on Professional Development of Pre-service English Teachers}

Through the retrieval of the relevant literature on the professional development of pre-service English teachers and the regulation and analysis of the corresponding high-frequency cited literature, it is found that the research results on the professional development of pre-service English teachers in recent years mainly focus on the following aspects: 
TABLE 2

High-FREQUENCY Cited Literature ON PRE-SERVICE ENGLISH TEACHERS IN CHINA AND ABRoAD

\begin{tabular}{|c|c|c|c|c|c|}
\hline 序号 & 文献名称 & 作者 & 出版年份 & 类型 & 出版源 \\
\hline 1 & Hand book of research on teacher education & Houston & 1990 & [M] & University of Chicago Press \\
\hline 2 & Teacher development and educational change & Fuller \& Hargreaves & 1992 & {$[\mathrm{M}]$} & Falmemer Press \\
\hline 3 & $\begin{array}{l}\text { Effective peer mentoring for EFL Pre-service teachers' } \\
\text { instructional practicum practice }\end{array}$ & Nguyen & 2010 & {$[\mathrm{~J}]$} & EFL Journal Quarterly \\
\hline 4 & $\begin{array}{l}\text { TESOL in Context: Authentic workplace learning } \\
\text { for pre-service teachers }\end{array}$ & $\begin{array}{|lll|}\begin{array}{l}\text { Thomsett \& Leggett \& } \\
\text { Ainsworth }\end{array} & \\
\end{array}$ & 2011 & {$[\mathrm{~J}]$} & EBSCO \\
\hline 5 & $\begin{array}{l}\text { Me like Pre-service EFL teacher learning during the } \\
\text { practicum: A multiple case study in a context of } \\
\text { systemic dissonance }\end{array}$ & Bulut & 2016 & {$[\mathrm{D}]$} & University of Leeds \\
\hline 6 & 教育实习与职前英语教师专业发展关系探究 & 郭新婕, 王蓄 & 2009 & {$[\mathrm{~J}]$} & 外语与外语教学 \\
\hline 7 & 中国基础教育阶段外语教师的职前教育研究 & 邹为诚 & 2009 & {$[\mathrm{~J}]$} & 外语教学理论与实践 \\
\hline 8 & 教育信息化背景下职前外语教师技术倾向研究 & 李涛,欧阳护华 & 2017 & {$[\mathrm{~J}]$} & 外语电化教学 \\
\hline 9 & \begin{tabular}{|l} 
职前外语教师科研参与状况及影响机制 调查研究 \\
一一以学科教学(英语)专业学位研究生为例 \\
\end{tabular} & 寻阳 & 2018 & {$[\mathrm{~J}]$} & 山东外语教学 \\
\hline 10 & “互联网+” 中学教师职前专业能力发展研究 & 李钢, 范丽娜, 李金姝 & 2019 & {$[\mathrm{~J}]$} & 湖南师范大学教育科学学报 \\
\hline
\end{tabular}

Through the keyword search of professional development of pre-service English teachers and the corresponding regularity and analysis, it is found that the research results on professional development of pre-service English teachers in recent years mainly focus on the following aspects.

Abroad research on pre-service English teachers from the beginning of the definition of language teachers to enhance the second language teacher identity definition, research topics, research methods and other aspects of cognition, second language teacher identity research focus on pre-service teachers and in-service teachers, and pre-service teacher identity research is significantly more than in-service teacher identity research, most of the research uses qualitative research methods, there are theoretical studies mainly to explore the second language teacher identity shaping factors, second language teacher identity change, English or non-English teachers division and second language teacher identity construction and other topics, empirical research focuses on pre-service teachers' educational practice.

However, the research on the status of foreign language teachers in China started late and is mostly a summary of western research results. Moreover, the research focuses on the clarification of related concepts and the exploration of teachers' professional development. The research objects are mainly teachers in higher education and in-service, and pay less attention to pre-service English teachers. In the future, many scholars believe that the factors of English teachers' professional development should change from static research to dynamic improvement, from external factors to internal driving force, and from traditional mode to educational information-based mode.

\section{SUMMARY}

Through the above literature review of mobile assisted language learning and professional development of pre-service English teachers, the author finds that with the further development of teachers' specialization, the relevant research on pre-service teachers is gradually being paid attention to. However, the domestic research on pre-service English teachers needs to be improved. The professional development of pre-service English teachers is the knowledge and specialization of teachers to prepare for future English teachers during pre-service education. In recent years, mobile learning has become one of the most popular learning methods under the background of the integration of information technology and subject teaching. But it also poses new challenges to teachers' professional development. Therefore, it is also very important to cultivate pre-service English teachers' information technology literacy in foreign language education research. Through the reference of relevant literature, the author finds that the domestic research on pre-service English teachers is mainly about the status and practical process of pre-service English teachers. Few scholars pay attention to the professional development of pre-service English teachers in information technology, especially mobile learning. Therefore, this topic combines the application of mobile learning in education and teaching under the development of information technology with the professional development of pre-service English teachers in order to improve the information technology literacy of pre-service English teachers. Based on the results of literature analysis, the author summarizes the current situation of language learning supported by mobile technology in China and points out the research. In view of the above review and analysis, the authors think that in order to improve the effect of teachers' informal learning under the mobile Internet, we must make efforts from the aspects of teachers themselves, school management, learning resources and network environment.

(1) Correct learning attitude and raise learning awareness

Teachers should make it clear that human beings acquire more than $80 \%$ knowledge through informal learning, and the role of informal learning in our daily production and life is self-evident. At the same time, the concept of lifelong learning is indispensable in this increasingly competitive and challenging society. As teachers with educational mission, they should bear the brunt and become the guide and role model of lifelong learning in this society. In the new era of scientific and technological innovation, informal learning based on mobile Internet is an important way for teachers to improve their professional level. Only on the premise of affirming the importance of informal learning can teachers 
have strong learning motivation and maintain a positive learning attitude in informal learning. Learning motivation is the driving force for all human beings to learn. It plays the role of encouragement, persistence and self-regulation, and is the basis of all learning activities. Learning attitude is also an important guarantee to promote the effective development of learning activities. As Hill, a famous American scholar, said ," there are two things that can not be separated from human achievements today, one is ability, the other is attitude." the importance of learning attitude can be seen.

(2) Strengthen the construction of learning resources of mobile network.

Learning content is a very important part of teachers' informal learning process. The quality of learning content directly determines the quality of learning results. In order to be targeted, we must fully grasp the characteristics of informal learning, classify the learning content, and make the knowledge points more refined, so that teachers can learn in pieces anytime and anywhere. At the same time, in the process of learning resources presentation, we should minimize the occurrence of content unrelated to normal learning. Learning content in the process of display should be as diverse as photos, moving pictures, video and other presentation methods, in order to stimulate teachers' interest in learning, but also conducive to the storage and memory of useful knowledge.

(3) Strengthen the network security management.

A harmonious and healthy mobile Internet environment is an important guarantee for most teachers to carry out informal learning spontaneously. When teachers get information hungry on the Internet, they often have no time to take into account some bad information, and may click on some unsafe links in the unconscious, which will not only affect the teacher's body and mind. It is also possible to bring money losses. The ultimate influence is teachers' confidence and enthusiasm for informal learning in mobile environment. Therefore, relevant departments should pay attention to Internet security issues and improve relevant laws and regulations. Those who publish bad information and create bad websites should be severely punished. At the same time, it is necessary to strengthen the professional technical support and security of relevant forums, learning platforms or learning websites, so that teachers can carry out informal learning with a relaxed and pleasant attitude under the mobile Internet, which can greatly improve the efficiency and results of teachers' informal learning.

(4) Establish a network learning community for teachers in or between schools.

In Internet plus era, the increase and share of data grow with each passing day, which brings opportunities for schools to form new teaching and research organizations. Teachers' network cooperative community emerges as the times require. This kind of community, whether in the form of QQ, Wechat or other apps, integrates online discussion, interaction and sharing as one platform, providing teachers with a community space for common learning. In this learning organization, the school encourages teachers to carry out teaching research, not only to be the enjoyment of network resources, but also to be the builder of network resources, and constantly create excellent teaching resources, so as to better promote the accumulation of teachers' teaching knowledge, improve the level of professional skills, and become mature in professional psychology.

(5) To ensure the effective operation of mobile e-learning community.

First of all, the school should formulate scientific and reasonable informal learning rules of mobile Internet, that is, the specific learning rules of e-learning community, such as the composition of learning group members, activity attendance, learning content, learning form, learning time and member performance evaluation. Secondly, the school should strengthen the active operation of the network community. This requires schools to carry out more informal learning activities with the help of mobile network, so that teachers' learning can break through the limitations of time and place, and can be involved in the upsurge of mobile learning anytime and anywhere. We should not let the network community become a mere formality and empty platform. We should give more play to the power of mutual supervision and progress among the members of the lesson preparation group and the teaching and research group, encourage teachers to share, interact and communicate more, and give full play to the power of peer support. In addition, schools should establish clear incentive measures for teachers' Informal Learning under the mobile Internet. Regularly carry out a variety of activities related to knowledge competition or teaching resources informatization, and give material and spiritual rewards to teachers with outstanding performance, which can greatly enhance teachers' enthusiasm for online learning.

\section{REFERENCES}

[1] Abdous, M. H., Camarena, M. M., \& Facer, B. R. (2009). MALL technology: Use of academic podcasting in the foreign language classroom. ReCALL, 21: 76-95.

[2] Bulut. (2016). Me like Pre-service EFL teacher learning during the practicum: A multiple case study in a context of systemic dissonance, Ph.D. dissertation, University of Leeds.

[3] Chen, C. M., \&Chung, C. J. (2008). Personalized mobile English vocabulary learning system based on item response theory and learning memory cycle. Computers \& Education, 51,624-645.

[4] Chen Jianlin. (2010). Integration of Computer Networks and Foreign Language Courses Shanghai: Shanghai Foreign language Education Press.

[5] Chen Zhenzhen. (2019). A Study on the Learning Input of Smartphone Assisted Foreign Language Teaching in Classroom Teaching. Audio-visual Teaching of Foreign languages 6, 49-54.

[6] Clark N. Quinn. (2010). The Mobile Academy: M learning For Higher Education. San Francisco, California, Jossey-Bass Press. 
[7] Comac, L. (2008). Using audioblogs to assist English-language learning: an investigation into student perception. Computer Assisted Language Learning, 21, 181- 198.

[8] Cui Guangzuo et al. (2001). Mobile Education — a New Direction of Modern Educational Technology National Higher Education Technical Cooperation Committee. Theory and Practice-E-Learning Research and Application of Modern Educational Technology. Chongqing, southwest normal University Press.

[9] Frohberg \&C. Göth \&G. Schwabe. (2009). Mobile Learning projects-a critical analysis of the state of the art. Journal of Computer Assisted Learning, 25,307-331.

[10] Golonka, E. M., Bowles, A. R., Frank, V. M., Richardson, D. L. \& Freynik, S. (2012). Technologies for foreign language learning: A review of technology types and their effectiveness. Computer Assisted Language Learning, 27, 70-105.

[11] Kukulska-Hulme. (2009). Will mobile learning change language learning? ReCALL, 21, 157-165.

[12] Li Gang, Fan Lina, Li Jinshu. (2019). A Study on the Development of Pre-service Professional Competence for Middle School Teachers. Internet Journal of Educational Science, Hunan normal University, 01, 102-107.

[13] Lu Yingbo, Yu Ping. (2013). A Study on the Mode of Foreign Language Teaching Based on Mobile Learning Terminal. Modern Educational Technology, 6, 71-75.

[14] Mingucci, M. M. (2002). AR as ESL Teacher Professional Development. University of Misouri-Kansas City.

[15] Tian Hanzu. (2014). Qi Yujie, Li Danhua. Current Situation, Problems and Countermeasures of Teachers' Exchange in Compulsory Education in Beijing. Educational science research, (12):24-30 36.

[16] Wen Qiaoping. (2007). A Reflections on the Intension of Foreign Language Teachers' Professional Development. Journal of Hunan Agricultural University (Social Sciences Edition), (01):87-89.

[17] Xiao Liping. (2002). A Review of the Research on Teacher Professional Development at Home and abroad. Chinese Journal of Education, (05):61-64.

Miaomiao Gao was born in Shanxi, China in 1996.

She is currently a postgraduate student in the School of Foreign Languages, Chongqing Normal University, Chongqing, China. Her research interests include English Education and text book analysis.

Ms. Gao is a member of the postgraduate student research innovation project in Chongqing.

Xifang Tu was born in Jiangxi, China in 1996.

She is currently a postgraduate student in the School of Foreign Languages, Chongqing Normal University, Chongqing, China. Her research interests include English Education and second language acquisition.

Ms. Tu is a member of the postgraduate student research innovation project in Chongqing.

Junshui Li was born in Fujian, China in 1995.

$\mathrm{He}$ is currently a postgraduate student in the School of Foreign Languages, Chongqing Normal University, Chongqing, China. His research interests include Cognitive linguistic and Mobile-Assisted language learning.

$\mathrm{Mr} . \mathrm{Li}$ is a member of the postgraduate student research innovation project in Chongqing. 